\title{
Article
}

\section{Evaluation of Wheat Resistance to Snow Mold Caused by Microdochium nivale (Fr) Samuels and I.C. Hallett under Abiotic Stress Influence in the Central Non-Black Earth Region of Russia}

\author{
Sulukhan K. Temirbekova ${ }^{1}$ (D, Ivan M. Kulikov ${ }^{2}$, Mukhtar Z. Ashirbekov ${ }^{3}$, Yuliya V. Afanasyeva ${ }^{2}{ }^{\mathbb{D}}$, \\ Olga O. Beloshapkina ${ }^{4}$, Lev G. Tyryshkin ${ }^{5}{ }^{\complement}$, Evgeniy V. Zuev ${ }^{5}{ }^{\complement}$, Rima N. Kirakosyan ${ }^{4}$, Alexey P. Glinushkin ${ }^{1}$, \\ Elena S. Potapova ${ }^{4}$ and Nazih Y. Rebouh ${ }^{6, *(\mathbb{D})}$
}

check for updates

Citation: Temirbekova, S.K.; Kulikov, I.M.; Ashirbekov, M.Z.; Afanasyeva, Y.V.; Beloshapkina, O.O.; Tyryshkin, L.G.; Zuev, E.V.; Kirakosyan, R.N.; Glinushkin, A.P.; Potapova, E.S.; et al. Evaluation of Wheat Resistance to Snow Mold Caused by Microdochium nivale (Fr) Samuels and I.C. Hallett under Abiotic Stress Influence in the Central Non-Black Earth Region of Russia. Plants 2022, 11, 699. https:// doi.org/10.3390/plants11050699

Academic Editors: Jemanesh Haile and Amidou N'Diaye

Received: 31 January 2022

Accepted: 2 March 2022

Published: 4 March 2022

Publisher's Note: MDPI stays neutral with regard to jurisdictional claims in published maps and institutional affiliations.

Copyright: (C) 2022 by the authors. Licensee MDPI, Basel, Switzerland. This article is an open access article distributed under the terms and conditions of the Creative Commons Attribution (CC BY) license (https:// creativecommons.org/licenses/by/ $4.0 /)$.
1 All-Russian Research Institute of Phytopathology, Bolshye Vyazyomy, Odintsovo District, 143050 Moscow, Russia; sul20@yandex.ru (S.K.T.); glinale1@mail.ru (A.P.G.)

2 Federal Horticultural Center for Breeding, Agrotechnology and Nursery, 115598 Moscow, Russia; vstisp@vstisp.org (I.M.K.); yuliya_afanaseva_90@bk.ru (Y.V.A.)

3 Department of Agronomy and Forestry, Faculty of Agronomy, Manash Kozybayev North Kazakhstan University, 150000 Petropavlovsk, Russia; mukhtar_agro@mail.ru

4 Department of Biotechnology, Moscow Timiryazev Agricultural Academy, Agrarian University, 127550 Moscow, Russia; beloshapkina58@mail.ru (O.O.B.); r.kirakosyan@rgau-msha.ru (R.N.K.); dac.taer2010@yandex.ru (E.S.P.)

5 N.I. Vavilov All-Russian Institute of Plant Genetic Resources (VIR), Bolshaya Morskaya Str. 42-44, 190000 Saint Petersburg, Russia; tyryshkinlev@rambler.ru (L.G.T.); e.zuev@vir.nw.ru (E.V.Z.)

6 Department of Environmental Management, Peoples' Friendship University of Russia (RUDN University), 6 Miklukho-Maklaya Street, 117198 Moscow, Russia

* Correspondence: n.yacer16@outlook.fr; Tel.: +7-9-774-188-644

Abstract: Microdochium nivale is one of the most harmful fungal diseases, causing colossal yield losses and deteriorating grain quality. Wheat genotypes from the world collection of the N.I. Vavilov Institute (VIR) were evaluated for fifty years to investigate their resistance to biotic stress factors (M. nivale). Between 350 to 1085 of winter wheat genotypes were investigated annually. Ten out of fifty years were identified as rot epiphytotics (1978, 1986, 1989, 1990, 1993, 1998, 2001, 2003, 2005 and 2021). The wheat collection was investigated by following the VIR methodological requirements and CMEA unified classification of Triticum aestivum L. The field investigations were carried out in the early spring during fixed-route observations and data collection was included on the spread and development degree of the disease, followed by microbiological and microscopic pathogen identifications. The observations revealed that the primary reason for pink snow mold to infect the wheat crops was abiotic stress factors, such as thawed soil covered in snow that increased the soil temperature by $1.0-4.6^{\circ} \mathrm{C}$ above normal. Under these conditions, the plants kept growing, quickly exhausting their carbohydrate and protein resources, thus weakening their immune systems, which made them an easy target for different infections, mainly cryophilic fungi, predominantly Microdochium nivale in the Moscow region. In some years, the joint effect of abiotic and biotic stresses caused crop failure, warranting the replanting of the spring wheat. The investigated wheat genotypes exhibited variable resistance to pink snow mold. The genotypes Mironovskaya 808 (k-43920) from Ukraine;l Nemchinovskaya 846 (k-56861), from Russia; Novobanatka (k-51761) from Yugoslavia; Liwilla (k-57580) from Poland; Zdar (UH 7050) from the Czech Republic; Maris Plowman (k-57944) from the United Kingdom; Pokal (k-56827) from Austria; Hvede Sarah (k-56289) from Denmark; Moldova 83 (k-59750) from Romania; Compal (k-57585) from Germany; Linna (k-45889) from Finland and Kehra (k-34228) from Estonia determined the sources, stability and tolerance to be used in advanced breeding programs.

Keywords: biotic stresses; fungal pathogens; pink snow mold; VIR gene pool; wheat breeding 


\section{Introduction}

Winter crop rot is a complex process that is observed in plants spending a long time at a temperature close to $0{ }^{\circ} \mathrm{C}$ in relatively warm soil, without sunlight and under a thick snow cover $[1,2]$. Under such conditions, the plants quickly burn the nutrients accumulated in their leaves and tillering nodes, hence weakening their nonspecific resistance, and become an easy target for fungal infection, most commonly snow mold and sclerotinia [3].

In mycology, low-temperature fungal pathogen spreading under snow cover had been termed 'psychrophilic' until Hoshino, Matsumoto [4] coined another name, 'cryophilic', meaning the fungi spend a part or their whole life cycle (in the sexual or asexual state) in a cryosphere, when the biosphere is either constantly or seasonally covered with snow and ice. According to the literature, the pathogenic fungi infecting plants under snow cause a disease known as "snow mold".

Snow mold, caused by Microdochium nivale (Fr) Samuels and I.C. Hallett, Microdochium majus (Wollenw.) Glynn and S.G. Edwards, Typhula idahoensis, T. ishikariensis, T. incarnata, Myriosclerotinia borealis, Pythium iwayami and P. okanoganense, is a devastating disease affecting a broad range of small grain cereals $[5,6]$. M. nivale and M. majus are the most harmful species among the snow mold-causing pathogens. Pink snow mold caused by $M$. nivale is associated with leaf and stem desiccation, extensive growth of white or pink mycelium and the formation of orange sporodochia, which is expressed in bleached-toorange-brown patches of matted leaf tissue [7]; this fungal pathogen is frequently noticed in grain cereals, affecting seed germination, as well as influencing the pre- and post-emergence death of seedlings, leading to significant yield losses [8-10].

Control of the M. nivale, therefore, in most cases is carried out by seed treatment, using fludioxonil and demethylation-inhibiting fungicides, such as difenoconazole, tebuconazole, prothioconazole, bitertanol, etc. [11,12]. Oliver et al. 2013 [13] investigated the effect of microwaves on the fungal pathogens of winter wheat and showed that microwaving significantly reduced $M$. nivale contamination levels on seeds. In addition, the control of $M$. nivale can be achieved by employing crop rotation [14]. In fact, the production of volatile sulfur compounds and soil microbial community composition seems to be effective in controlling M. nivale, as demonsrated by Vito et al. [15]. The authors found that the incidence and severity of M. nivale were reduced using Brassica carinata as precursor crops.

It is well known that the quantity of fertilizers has a significant impact on root rot disease reduction $[16,17]$. In fact, fertilization, as a conventional agricultural practice, influences the microflora of the soil by changing its chemical composition and physical characteristics. Dordas, 2009 [18] demonstrated that the mode of action of M. nivale differed according to nitrogen $(\mathrm{N})$, phosphate $(\mathrm{P})$ and potassium $(\mathrm{K})$ inputs. Previous studies have shown that the high levels of nitrogen $(\mathrm{N})$ applied seem to decrease the severity of root rot infections by enhancing plant physiology [19]. Potassium, when applied at optimal rates, is also known to have the capacity to reduce the host plant's susceptibility to fungal infections. However, phosphate's role in plant resistance to pathogens varies considerably [20].

Wheat breeding, so far, has managed to increase grain yield as well as resistance to biotic and abiotic stresses factors. Breeding for disease resistance in wheat has a long and largely successful history [21]. In fact, many studies have demonstrated that the varietal selection and breeding methods are the most reliable and cost-effective method of controlling diseases, especially M. nivale [22,23], by developing new cultivars of wheat with disease-resistant characteristics. Plant breeding methods, such as backcross, screening germplasm for resistance sources, the hybridization of selected parents, the selection and evaluation of hybrids and the testing and release of new varieties, are effective methods to transfer one or a few genes controlling a specific trait from one line into a second, usually elite, breeding line, despite the difficulties encountered in terms of time and resources [24,25].

In Russia, the N.I. Vavilov Institute (VIR) is making much effort to develop new varieties focused on varietal resistance to diseases, particularly $M$. nivale, which causes quantitative and qualitative damage to wheat due to the climatic specificity of the central 
non-black earth region that promotes the development of this disease. The wheat genotypes from the (VIR) world collection can be an important source of resistance to both abiotic and biotic stress factors $[3,26]$. The purposes of this study is to investigate the gene pool of winter wheat genotypes from the world collection of VIR and identify the sources of resistance to $M$. nivale for future breeding programs.

\section{Results}

The results of the current study represent exploration of the winter wheat gene pool from the VIR world collection in order to detect new sources of resistance to Microdochium nevale. During the epiphytotic years, the dominated fungal pathogen causing snow mold in the Moscow region was M. nivale. The fungus's conidial (anamorphic) stage belongs to the Hyphomycetes class, Tuberculariales order, Tuberculariacea family and Microdochium genus. Its teleomorph (ascigerous) stage-Monographella nivalis var. nivalis-belongs to the Ascomycota phylum, Euascomycotinae subphylum, Hypocreales order, Nectriaceae family and Monographella genus. The fungus has colorless (pink in mass) fusiform conidia of 14-25 × 3-4 $\mu \mathrm{m}$ in size (Figure 1). Except for conidial sporulation, it also forms an ascigerous stage of surface perithecia found in the bottom part of a plant's stem, and its ascospores infect the upper leaves in spring and summer when the weather is wet and cool. The fungus's asci have a thin claviform envelope of 50-70 $\times 8-10 \mu \mathrm{m}$ and contain 6-8 spores. Mature ascospores are smooth, of straight or bent ellipsoid shape and have from 1 to 3 septa. Before 1980, it was known as Fusarium nivale. Since the beginning of 1980 it has been known as $M$. nivale. Currently, the fungus is known by its teleomorph stage as Monographella nivalis var. nivalis [4].

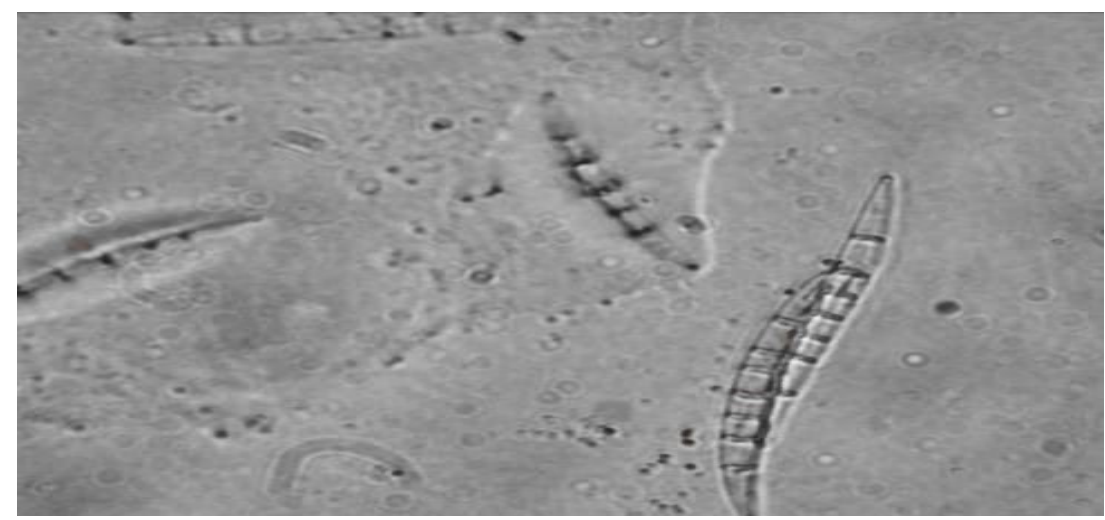

Figure 1. Microdochium nivale (Fr.) Samuels and I.C. Hallett (a.k.a Fusarium nivale (Fr.) Ces.ExBerl. and Voglino) conidia (scale bar: $10 \mu \mathrm{m}$ ).

The observations over the years allowed to point out 10 years of rot epiphytotics in the central non-black earth region of Russia, namely 1977-1978, 1985-1986, 1988-1989, 1989-1990, 1992-1993, 1997-1998, 2000-2001, 2002-2003, 2004-2005, 2020-2021. The short description of these years is as follows:

Year 1977-1978. Snow fell on thawed soil when the air temperature was $1^{\circ} \mathrm{C}$ above the average perennial winter temperature $\left(-9.9^{\circ} \mathrm{C}\right)$. The height of snow cover was $30-40 \mathrm{~cm}$. After the snow melted, collection plants started to die due to progressing snow mold. Only 270 out of 900 genotypes survived. Phytopathological assessment of 630 dead genotypes indicated $M$. nivale as a dominating pink snow mold pathogen.

The following varieties demonstrated higher resistance and tolerance to the pathogen (resistance score 7-9; fungal lesion 10-15\%): Mironovskaya 808 (k-43920) from Ukraine; Zarya (k-49916) from Russia; Walde (k-51794) from Sweden; Hadmersleben 21687/69 (k50455), Felakrone (k-50768) from Germany; Antti (k-42673), Jo 832 (k-44775) from Finland; Progress (k-50584), Rizynska 105/71 (k-50603) from Czechoslovakia; Aria (k-50723) from 
Poland. The genotypes that did not survive mainly came from the countries of Western Europe and Russia's Krasnodar Region.

Year 1985-1986. This winter period was characterized by a high snow cover of $40-50 \mathrm{~cm}$. The snow-cover thawed soil and the season was intermitted by thawing weather $\left(2-4{ }^{\circ} \mathrm{C}\right)$, so the soil had not frozen up till the middle of the winter. In the third week of January, snowing was sometimes intermitted by rain, and the temperature increased by $3{ }^{\circ} \mathrm{C}$ from the normal January temperature of $-11^{\circ} \mathrm{C}$. Under such conditions, to reduce the temperature in the upper layer of the soil, a snow packing procedure was performed. The long-lasting period of positive temperatures had exhausted the plants and facilitated pink snow mold spread by the end of the winter that was demonstrated by phytopathological analysis. Of 500 genotypes, 353 died, and 132 demonstrated enough tolerance to the disease. These included: Sv 75,268 (k-56156), Helge (k-56872), WW23977 (k-56875), Hildur (k-54130), Sv VG74393 (k-56065), Sv 01,744 (k-56159) from Sweden; TAW37564 (k-55939), TAW5127.72 (k-55940) from Germany; L'vovskaya ostistaya (k-55767) from Ukraine; Novobanatka (k-51761) from Yugoslavia; RMO (k-55220) from Poland.

Year 1988-1989. The winter was very warm, so the average monthly temperature in January-March exceeded the norm $\left(8.9^{\circ} \mathrm{C}\right)$ by $9.1{ }^{\circ} \mathrm{C}$. A rare phenomenon of unfrozen soil covered by a thick $(60 \mathrm{~cm})$ snow layer was observed. Despite the packing, the plants succumbed to the pathogen; from 500 genotypes only 350 survived. The highest resistance and tolerance to the pathogen was demonstrated by some highly productive genotypes of $450-630 \mathrm{~g} / \mathrm{m}^{2}$ in crop yield and 40-47 $\mathrm{g}$ in 1000-grain weight, such as the Mironovskaya standard (808-365 g/ $\mathrm{m}^{2}$ and $47 \mathrm{~g}$ ). These included: PP114-74 (k-57618), Liwilla (k-57580) from Poland; Zdar (UH 7050) (k-57255) from the Czech Republic; Maris Plowman (k57944) from the United Kingdom; Compal (k-56904), Caristerm (k-57610), Fakta (k-57582) from Germany; Helge (k-56872), Salut (k-58035) from Sweden; Raduga (k-50948), Nemchinovskaya 846 (k-56861), Nemchinovskaya 110 (k-56858), Lutescens 497.83 (k-57657) from Russia (Table 1).

Table 1. Yield of the resistant genotypes (1988-1989).

\begin{tabular}{ccc}
\hline & Resistant Genotypes & \\
\hline Genotypes & Country & Yield g/m $\mathbf{m}^{\mathbf{2}}$ \\
\hline Mironovskaya st & Ukraine & 365 \\
PP114-74 (k-57618) & Poland & 615 \\
Liwilla (k-57580) & Poland & 630 \\
Zdar (UH 7050) & Czech Republic & 595 \\
Maris Plowman (k-57944) & United Kingdom & 545 \\
Caristerm (k-57610) & Germany & 585 \\
Fakta (k-57582) & Germany & 575 \\
Compal (k-57585), & Germany & 565 \\
Helge (k-56872) & Sweden & 450 \\
Salut (k-58035) & Sweden & 550 \\
Raduga (k-50948) & Russia & 570 \\
Nemchinovskaya 846 (k-56861) & Russia & 630 \\
Nemchinovskaya 110 (k-56858) & Russia & 610 \\
Lutescens497.83 (k-57657) & Russia & 590 \\
\hline
\end{tabular}

However, the genotypes Bu 22 (k-57603), So 1586 (k-57250), So 8123 (k-56913) from Czech Republic; Weihenstekhaner (и-0109306), Taw 34727/75 (k-55188), Turan (u-109808) from Germany, SMH-71 (и-099339) from Poland; Flambeau (1-56761), Rapier (k-56751), Longbow (k-57611) from United Kingdom; Russia (k-54039), Lutescens 1862 (k-58553), Chernozemka 153 (k-57982) from Russia and Dular (k-56156) from the USA were classified as not resistant to snow mold. Their crop yields were $125-366 \mathrm{~g} / \mathrm{m}^{2}$ (Table 2). 
Table 2. Yield of the non -resistant genotypes (1988-1989).

\begin{tabular}{ccc}
\hline & Non-Resistant Genotypes & \\
\hline Genotypes & Country & Yield g/m $\mathbf{m}^{\mathbf{2}}$ \\
\hline Bu 22 (k-57603) & Czech Republic & 245 \\
So 1586 (k-57250) & Czech Republic & 315 \\
So 8123 (k-56913) & Czech Republic & 290 \\
Weihenstekhaner (и-0109306) & Germany & 125 \\
Taw 34727/75 (k-55188) & Germany & 335 \\
Turan (u-109808) & Germany & 315 \\
SMH-71 (и-099339) & Poland & 325 \\
Flambeau (l-56761) & United Kingdom & 315 \\
Rapier (k-56751) & United Kingdom & 340 \\
Longbow (k-57611) & United Kingdom & 330 \\
Russia (k-54039) & Russia & 308 \\
Lutescens 1862 (k-58553) & Russia & 366 \\
Chernozemka 153 (k-57982) & Russia & 305 \\
Dular (k-56156) & USA & 320 \\
\hline
\end{tabular}

Year 1989-1990. Warm weather with positive $\left(2.4^{\circ} \mathrm{C}\right.$ above normal) temperatures in every winter month was typical for this season. A snow cover over thawed soil reached $60-70 \mathrm{~cm}$. Often, winter thawings exhausted the plants, causing their deaths. In spring, after the snow melted, the dead plants were found covered in the mycelium and conidial sporulation of pink snow mold. Out of 500, 164 genotypes died, mostly those from the countries of Western Europe and Russia's Krasnodar region. The highest resistance and tolerance to both abiotic and biotic factors was demonstrated by: Pokal (k-56827) from Austria; Hvede Sarah (k-56289) from Denmark; TAW4279180 (k-58363), Fakta (k-57582), Compal (k-57585), Fakon (k-58187), Kronjuwel (k-57615), TAW 39496.75 (k-56903) from Germany; Venture (k-57231) Longbow (k-57611), Granta (k-57219) from the United Kingdom; Sv75355 (k-56158) from Sweden; Titan (k-58059) from the United States; Erythrospermum 9736 (k-57479), Grekum 9271 (k-57472) from Ukraine; Yantarnaya 50 (k-54610), Nemchinovskaya 52 (k-59269), Belosnezhnaya (k-57573) from Russia. Their crop yields were 449-600 g/ $\mathrm{m}^{2}$ against $495 \mathrm{~g} / \mathrm{m}^{2}$ of the Mironovskaya standard (Table 3).

Table 3. Yield of the resistant genotypes (1989-1990).

\begin{tabular}{ccc}
\hline & Resistant Genotypes & \\
\hline Genotypes & Country & Yield g/m $\mathbf{~}^{\mathbf{2}}$ \\
\hline Mironovskaya st & Ukraine & 495 \\
Pokal (k-56827) & Austria & 520 \\
Hvede Sarah & Denmark & 537 \\
TAW4279180 (k-58363) & Poland & 496 \\
Fakta (k-57582) & Germany & 590 \\
Compal (k-57585), & Germany & 595 \\
Fakon (k-58187) & Germany & 511 \\
Kronjuwel (k-57615) & Germany & 600 \\
TAW 39496.75 (k-56903) & Germany & 548 \\
Venture (k-57231) & United Kingdom & 544 \\
Longbow (k-57611) & United Kingdom & 509 \\
Granta (k-57219) & United Kingdom & 490 \\
Sv75355 (k-56158) & Sweden & 527 \\
Titan (k-58059) & USA & 501 \\
Erythrospermum 9736 (k-57479) & Ukraine & 449 \\
Grekum 9271 (k-57472) & Ukraine & 513 \\
Yantarnaya 50 (k-54610) & Russia & 482 \\
Nemchinovskaya 52 (k-59269) & Russia & 565 \\
Belosnezhnaya (k-57573) & Russia & 468 \\
\hline
\end{tabular}


However, the genotypes Talon (k-62743), Peacock (k-62744), Fortress (k-62745), Admiral (k-62747) from United Kingdom, Accent (k-62843), Avir (k-62844), TMillev (k-62845) from Netherlands, Истра-1 62734 from Russia and Hjan Ilves (k-63015), Ilves (k-63016) from Finland were classified as not resistant to snow mold. Their crop yields were $45-245 \mathrm{~g} / \mathrm{m}^{2}$ (Table 4).

Table 4. Yield of the non-resistant genotypes (1989-1990).

\begin{tabular}{ccc}
\hline & Non-Resistant Genotypes & \\
\hline Genotypes & Country & Yield g/m $\mathbf{m}^{\mathbf{2}}$ \\
\hline Talon (k-62743) & United Kingdom & 245 \\
Peacock (k-62744) & United Kingdom & 45 \\
Fortress (k-62745) & United Kingdom & 70 \\
Admiral (k-62747) & United Kingdom & 145 \\
Accent (k-62843) & Netherlands & 135 \\
Avir (k-62844) & Netherlands & 95 \\
Millev (k-62845) & Netherlands & 45 \\
Hcrpa-1 62734 & Russia & 115 \\
Hjan Ilves (k-63015) & Finland & 125 \\
Ilves (k-63016) & Finland & \\
\hline
\end{tabular}

Year 1992-1993. In this season, snow covered warm soil and caused an ice layer to form. The temperature during winter months exceeded the average perennial winter norm $\left(-9.9^{\circ} \mathrm{C}\right)$ by $1-2{ }^{\circ} \mathrm{C}$. Seventy percent of the collection plants died after the snow melted and only $40 \%$ of the Mironovskaya 808 standard survived. The leaves and stems of the dead plants were covered in pink snow mold. At the level of the standard, a proper resistance to the infection was demonstrated by three genotypes: Moldova 83 (k-59750) from Romania; Sparta (k-60094) from Czechoslovakia; and Borden (k-50317), from Canada.

Year 1997-1998. The season was warm, but January and February did not give enough snow and the temperature was $3{ }^{\circ} \mathrm{C}$ above normal. The precipitation level was two times below normal. After the snow melted, 50-70\% of the collection plants either died or were severely infected by pink snow mold. The highest resistance and tolerance to both abiotic and biotic factors were demonstrated by: Mironovskaya 808 (k-43920) from Ukraine, Compal (k-57585), Tukan (k-57579) from Germany, Zarya (k-49916) from Russia; PE 649 (k-52656) from Finland; Sheriff Dickopf (k-40526), Sv 65646 (k-55305), WW 24089 (k-51803), Sv 61246 (1-47099) from Sweden, Salwa (u-538083) from Poland and Maris Marksman (k-55233) from United Kingdom.

The 1000-grain weight of these varieties varied between 39.3 and $41.5 \mathrm{~g}$, and the crop yields between 290 and $350 \mathrm{~g} / \mathrm{m}^{2}$, while, in the standards, these parameters were $45-56 \mathrm{~g}$ and $330-470 \mathrm{~g} / \mathrm{m}^{2}$, respectively (Table 5).

However, the genotypes Solid (k-51796) from Sweden, Kalininskaya 11 (k-46957), Erythrospermum 60 (k-50968) from Russia, Hohenthurmer 6831/68 (k-50470), Cyrano (k-51609), 618/67 (k-53517) and Duellant (k-53518) from Germany, WZ 945-13 (k-51713) from Netherlands, TJB 364/636 (k-53486) from United Kingdom and Hybrid (k-53500) from Denmark did not expressed resistance to snow mold. Their crop yields were $80-200 \mathrm{~g} / \mathrm{m}^{2}$ (Table 6).

Year 2000-2001. Thawings and rains were typical for this season in which the average temperature was $2-4{ }^{\circ} \mathrm{C}$ above normal. The precipitation level (193.9) also exceeded the norm $(111 \mathrm{~mm})$. The soil did not freeze up properly, causing a massive rot in the collection plants, so $60-80 \%$ of them died, with pink snow mold prevailing in the genotypes from Western Europe, the CIS countries and Russia. Out of 1058 varieties, the proper level of resistance (7-9 points) and tolerance to both abiotic and biotic factors at a crop yield of 300-420 g/m² was demonstrated by: Pamyati Fedina (k-62440), Lyutestsens 306 (k-58827), Lyutestsens 319 (k-59267), Ivanovskaya 16 (k-58526) from Russia; Kehra (k-34228) from Estonia; Varmlands (k-34230) from Sweden. 
Table 5. Yield of the resistant genotypes (1997-1998).

\begin{tabular}{ccc}
\hline & Resistant Genotypes \\
\hline Genotypes & Country & Yield g/m $\mathbf{m}^{\mathbf{2}}$ \\
\hline Mironovskaya st & Ukraine & 350 \\
Compal (k-57585) & Germany & 350 \\
Tukan (k-57579) & Germany & 310 \\
Zarya(k-49916) & Russia & 290 \\
Sheriff Dickopf (k-40526) & Sweden & 370 \\
Sv 65646 (k-55305) & Sweden & 346 \\
WW 24089 (k-51803) & Sweden & 345 \\
Sv 61246 (l-47099) & Sweden & 342 \\
Jo 01177 (k-44704) & Finland & 320 \\
PE 649 (k-52656) & Denmark & 335 \\
Salwa (u-538083) & Poland & 350 \\
Maris Marksman (k-55233) & United Kingdom & 370 \\
\hline
\end{tabular}

Table 6. Yield of the non-resistant genotypes (1977-1998).

\begin{tabular}{ccc}
\hline & Non-Resistant Genotypes & \\
\hline Genotypes & Country & Yield g/m $\mathbf{m}^{\mathbf{2}}$ \\
\hline Solid (k-51796) & Sweden & 200 \\
Kalininskaya 11 (k-46957) & Russia & 90 \\
Erythrospermum 60 (k-50968) & Russia & 175 \\
Hohenthurmer 6831/68 (k-50470) & Germany & 165 \\
Cyrano (k-51609) & Germany & 150 \\
618/67 (k-53517) & Germany & 130 \\
Duellant (k-53518) & Germany & 125 \\
WZ 945-13 (k-51713) & Netherlands & 145 \\
TJB 364/636 (k-53486) & United Kingdom & 80 \\
Hybrid (k-53500) & Denmark & 95 \\
\hline
\end{tabular}

Year 2002-2003. In this season, December had a small amount of snow, and January and February were very warm, with the temperature exceeding the norm by $1.9-4.6^{\circ} \mathrm{C}$, which had a negative effect on the winter wheat and caused its premature death. Out of 1200 collection varieties analyzed, the level of resistance and tolerance to pink snow mold at appropriate crop yield was demonstrated by: Pamyati Fedina (k-62440), Raduga (k-50948), Nemchinovskaya 24 (k-65757), Moskovskaya 56 (k-65760), Lutescens 319 (k-59267) and Ivanovskaya 16 (k-58526) from Russia; Varmlands (k-34230) from Sweden; Orestis (k-64034), Bussard (k-64027), Gelderseries (b/k) from Germany; Zenta (k-56825) from Switzerland; Compair (k-51913), Maris Ranger (k-50721), Rothwell Senator (k-50762) from the United Kingdom; standard Mironovskaya 808 (k-43920) from Ukraine- $280 \mathrm{~g} / \mathrm{m}^{2}$ (Table 7).

However, the genotypes KOS 1853/92 (k-63407), KOS 2696-93 (k-63420) from Russia, Chacay (k-63426) from Chile and Betta ( $k-63430)$ from South Africa were classified as not resistant to snow mold, with crop yields of $45-120 \mathrm{~g} / \mathrm{m}^{2}$ (Table 8 ).

Year 2004-2005. In this season, snow covered thawed soil and the temperature exceeded the norm by $2{ }^{\circ} \mathrm{C}$. The height of the snow cover was $20-25 \mathrm{~cm}$, causing ice layer formation. In spring, the plants died en mass due to pink snow mold infection. The phytopathological analysis detected M. nivale as the reason for death in 528 wheat varieties. The highest degree of resistance and tolerance were demonstrated by: Kazanskaya 560 (k63565), Karel'skaya bezostaya (k-40579) from Russia; k-15339 (Belarus), Tab 2598 (k-44326) from Finland. The standard was the variety Moskovskaya 39, with a 1000-grain weight of $39.7 \mathrm{~g}$ (Table 9). 
Table 7. Yield of the resistant genotypes (2002-2003).

\begin{tabular}{ccc}
\hline & Resistant Genotypes & \\
\hline Genotypes & Country & Yield g/m $\mathbf{m}^{\mathbf{2}}$ \\
\hline Mironovskaya st & Ukraine & 280 \\
Pamyati Fedina (k-62440) & Russia & 420 \\
Raduga (k-50948) & Russia & 910 \\
Nemchinovskaya 24 (k-65757) & Russia & 450 \\
Moskovskaya 56 (k-65760) & Russia & 400 \\
Lutescens 319 (k-59267) & Russia & 422 \\
Ivanovskaya 16 (k-58526) & Russia & 367 \\
Varmlands (k-34230) & Sweden & 302 \\
Orestis (k-64034) & Germany & 310 \\
Bussard (k-64027) & Germany & 400 \\
Gelderseries (b/k) & Germany & 490 \\
Zenta (k-56825) & Switzerland & 280 \\
Compair (k-51913) & United Kingdom & 965 \\
Maris Ranger (k-50721) & United Kingdom & 930 \\
Rothwell Senator (k-50762) & United Kingdom & 900 \\
\hline
\end{tabular}

Table 8. Yield of the nonresistant genotypes (2002-2003).

\begin{tabular}{ccc}
\hline & Non-Resistant Genotypes \\
\hline Genotypes & Country & Yield g/m $\mathbf{m}^{\mathbf{2}}$ \\
\hline KOS 1853/92 (k-63407) & Russia & 120 \\
KOS 2696-93 (k-63420) & Russia & 45 \\
Chacay (k-63426) & Chile & 55 \\
Betta (k-63430) & South Africa & 60 \\
\hline
\end{tabular}

Table 9. Yield of the resistant genotypes (2004-2005).

\begin{tabular}{|c|c|c|}
\hline \multicolumn{3}{|c|}{ Resistant Genotypes } \\
\hline Genotypes & Country & Yield $\mathrm{g} / \mathrm{m}^{2}$ \\
\hline Moskovskaya 39 st & Russia & 250 \\
\hline Kazanskaya 560 (k-63565) & Russia & 327 \\
\hline Karel'skaya bezostaya (k-40579) & Russia & 160 \\
\hline $\mathrm{k}-15339$ & Belarus & 295 \\
\hline Tab 2598 (k-44326) & Finland & 187 \\
\hline
\end{tabular}

However, the genotypes Tomo (k-63912) from United Kingdom, Rentol (k-64012) from Sweden and Czech Republic (k-63892) from South Africa did not express resistance to snow mold, with crop yields of $80-160 \mathrm{~g} / \mathrm{m}^{2}$ (Table 10).

Table 10. Yield of the nonresistant genotypes (2004-2005).

\begin{tabular}{ccc}
\hline & SNon-Resistant Genotypes \\
\hline Genotypes & Country & Yield $\mathbf{g} / \mathbf{m}^{\mathbf{2}}$ \\
\hline Tomo (k-63912) & United Kingdom & 80 \\
Rentol (k-64012) & Sweden & 110 \\
Siria (k-63892) & Czech Republic & 160 \\
\hline
\end{tabular}

Year 2020-2021. This year's snowfall was preceded by icy rain that fell on thawed soil. The temperature of the winter months was $1-3{ }^{\circ} \mathrm{C}$ above normal. The height of the snow cover reached 90-100 cm, causing ice layer formation. After the snow melted in spring, a significant spread of pink snow mold was observed, e.g., in the precision agriculture experiment carried out at Russian State Agrarian University-Moscow Timiryazev Agricultural 
Academy; the spread reached $94 \%$ in the Timiryazevska-Yubileinaya winter wheat and was not a focal phenomenon but covered almost the whole field [27].

In the year 2020-2021, the pink snow mold infection rate exceeded 10 times the average for the 50-year period due to the ice layer that formed following the snow that covered the thawed soil. The typical symptoms of the disease include stem bending, yellowing, leaf gluing and perishing (starting from peripheral ones) and plant death. The preserved leaves often had watery spots with a web-like mold of mycelium and conidial sporulation. After the leaves perished (Figure 2), the fungus attacked the tillering node (Figure 2a). In some years, microscopic investigation of dead plants made it possible to detect teleomorph sporulation (reddish rounded perithecia). In the extreme epiphytotic years $(1993,2001)$, the crop fields often had empty spots covered in perished leaves (Figure $2 b$ ) that sometimes occupied significant areas [28].

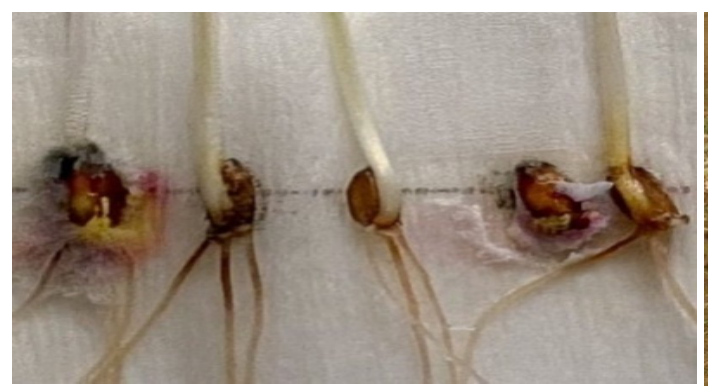

(a)

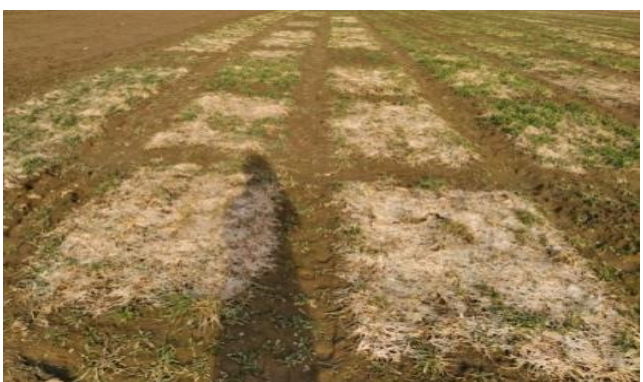

(b)

Figure 2. (a) - Grains infected by Microdochium nivale; (b) —an experimental field infected by $M i$ crodochium nivale, 2021.

\section{Discussion}

According to Bruehl. 1982 [29], the protracted snow cover forms a dark, humid environment with constant temperatures which reduces plant metabolism and prevents photosynthesis, thus decreasing the plants' immunity as well as promoting the development of psychrophilic fungi called snow molds, especially Microdochium nivale.

In the present study, annually, during the winter months, samples of soil with plants from the field were taken to analyze the condition of plants under snow cover in the laboratory. Over all the epiphytotic years, the depletion of plants due to their prolonged stay under the snow cover was noted, and pink snow mold damage was recorded only during early spring examination after snow melting. However, the dynamics of the development and the intensity of the plant infestation by the pathogen were not revealed. Moreover, the soil samples taken from the end of March to the beginning of April have revealed the presence of spores on the plants weakened by the abiotic stress. For that reason, we consider that the snow mold is a complex pathological process, initially launched by abiotic stress, followed by cryophilic fungal infection starting with sub-saprotrophic feeding on the weakened plants. Furthermore, many authors have studied the relationship between frost tolerance and snow mold resistance and have demonstrated that the resistance to low temperatures induces snow mold resistance [2,30]. In fact, for cryophilic fungi, the plants with disrupted physiological processes due to low temperatures, such as excessive breathing and premature decomposition of hydrocarbons into sugars and proteins into amides and amino acids, are an ideal nutritious substrate [3,31].

Annick et al. [23] showed that the tolerance of plants to frost allows them to acquire resistance to snow mold due to the high levels of carbohydrates after cold acclimation in frost-tolerant pants compared with sensitive plants. Pociecha et al. [32] demonstrated that the changes in biochemical parameters of the studied plants were observed after cold acclimation. Furthermore, Hiilovaara-Teijo et al. [33] found that, in response to cold, the resistant winter rye accumulated more proteins in the leaf apoplast. These results are in accordance with those reported in the present study and confirmed that snow 
mold infection start by sub-saprotrophic feeding on the weakened plants by biotic stress. Accordingly, we report that the joint effect of abiotic and biotic stresses sometimes causes complete crop failure, as it happened in 1993 and 2001.

The results of this 50-year study also allowed us to conclude that, for 40 years, the winter wheat overwintering was mainly affected by frost (abiotic stress). In this case, a snow layer covered not thawed but frozen soil, which is typical central non-black earth region of Russia. These years were cold, and their temperature varied within $-12-35{ }^{\circ} \mathrm{C}$. Under such conditions, no pink snow mold infection was observed. It is also noteworthy that for these years, the studied soil samples from winter and early spring times did not contain the pathogen and plants were not chlorotic, hence, they were not physiologically exhausted. In plate experiments, the optimum temperature for growth of $M$. nivale are around $-6.3^{\circ} \mathrm{C}$ and $-2.2{ }^{\circ} \mathrm{C}$ respectively [34].

The development of pink snow mold in the 2020-2021 growing year indirectly indicates the arrival of global climate warming on the planet, and it is possible that winter conditions similar to those prevailing in 2020-2021 will be frequent in the future. For that reason, plant breeders have to be ready to account for sudden warmings. Our study demonstrated that during the epiphytotic years, snow covering thawed soil made the winter wheat plants burn their nutrient reserves and continue the vegetation process to complete exhaustion. As a result, the plants weakened their immune systems and were unable to restore since photosynthesis is not possible without sunlight, i.e., they died of exhaustion due to the lack of sunlight, having depleted their carbohydrate and protein reserves. At that moment, cryophilic fungi became harmful, dominated by $M$. nivale, a pink snow mold pathogen causing mass crop mortality. When emerging from under the snow, some samples were found in the lesions with dead grayish and brownish-yellow leaves and with a pink coating on the leaves and the seed (Figure 2a). It is still discussable whether the fungicide spraying recommended by several researchers and performed in spring after snow melts can be effective [35]. In our experience, at a high infection rate, it does no good and further suppresses the exhausted plants (Figure 2b). The only way to reduce the damage and save the plants is through agrotechnical methods combined with nitrogen fertilization in spring.

Soil and plant residuals are the main source of infection. The pathogen can spread along a soil surface and can get into soil, especially when the temperature is low. In the soil, the fungus's conidia survive for 30 days or more, as demonstrated by Couteaudier et al. [36]. However, it is noteworthy that they become active only when the plants are weakened by abiotic stresses. In this respect, Microdochium nivale can be defined as one of the most harmful pathogens causing pink snow mold in the winter wheat under the central non-black earth region of Russia conditions. In view of the lack of relevant research to distinguish cultivars resistant to $M$. nivale, this study has been directed to the investigation of the gene pool of winter wheat from the VIR world collection to estimate their resistances and tolerances to this complex conjugate condition. It has enabled us to detect highly resistant and tolerant cultivars originating from different countries and having the resistance rate of 7-9 points at the prevalence rate of 10-15\%. These include: Linna (k-45889), Hja 24499 (k-62273) from Finland; WW 23262 (k-51808), Holger (k-62310), Sheriff Dickopf (k-40526), Svalofs Sonnet II (k-45132), Sv 6246 (k-47099), WW 24089 (k-51803), Konsul (k-64011), Sv 65646 (k-55305), Hildur (k-54130), Kosack (k-58137) from Sweden; Bijon (k-59520), Otto (k-59527) from Belgium; PP 114-74 (k-57618), Boxer (k-59536), Beauford (k-63920), Liwilla (k-57580) from Poland; Hornet (k-60100), Legend (k-61498), Maris Plowman (k-57944), Wizard (k-57229) from the United Kingdom; PE 6490 (k-52656), Trifolium 33 (k-56290) from Denmark; Zdar (k-57255) from the Czech Republic; Remus (k-56904), Caristerm (k-57610), Tukan (k-57579), Zentos (k-64030), Fazit (k-64032), Bussard (k-64027), Faktor (k-64028), Olimp (k-61455), Aron (k-64007), Apollo (k-61463), Criewener 2865/69 (k-52862) from Germany; Pammets (k-26236) from Norway; Raduga (k-50948), Nemchinovskaya 846 (k-56861), Nemchinovskaya 52 (k-59269), Lutescens 497/83 (k-57657), Shatilovskaya (k-37478), Lutescens 103 (k-55955), Lutescens 99 (k-55956), Sibirskaya Ul’yanovka (k-56057), 
MRt-833 (k-59228), MRt-340 (k-59233), M 15/6 ostistyy (k-59239), MGs-2287-t (k -60071) from Russia; Suzorie (k-59245) from Belarus; Brigantine (k-55181) from Ukraine.

The winter wheat variety Moskovskaya 39 was created on the basis of the genotypes selected during this study. Polityko et al. [37] investigated the potential of winter wheat variety Moskovskaya 39. The authors showed that higher values, in term of grain quality, weight of 1000 grains, gluten and protein content in grain, flour strength, porosity and resistance to fungal diseases, especially to M. nivale, were observed in the variety Moskovskaya 39 among seven studied varieties of winter wheat.

In the 21st century, the climate is expected to warm in Russia, the countries of Western Europe and Africa [38], so we recommend the potential sources of high resistance and tolerance to Microdochium nivale to be used in these countries for breeding adaptive varieties that produce a large yield of high-quality grain.

\section{Material and Methods}

\subsection{Experimental Site}

The field experiment was carried out at the Federal Horticultural Center for Breeding, Agrotechnology and Nursery, in the department of the gene pool and biological resources of plants, the former Moscow branch of the VIR. It is located in the village of Mikhnevo, Moscow region, in the central part of the southern Taiga forest soil-climatic zone (central non-black earth region of Russia).

\subsection{Climatic Conditions and Soil Characteristics}

The climate of Moscow region is moderately continental and humid. The average annual precipitation was $450-800 \mathrm{~mm}$, and the moisture was sufficient in years with normal precipitation. The probability of excessively wet years was $25-40 \%$, and that of arid and semiarid years about $12-20 \%$. Accumulated temperatures above $10{ }^{\circ} \mathrm{C}$ decreased from $2100^{\circ}$ in the east and south-east to $1900^{\circ}$ in the northwest, and vegetation periods (above $10^{\circ} \mathrm{C}$ ) decreased accordingly from 140-145 to 120-125 days [39].

About $70 \%$ of precipitation was recorded in the warm season, which ensures favorable conditions for plant growth and development. Soils freeze to the depths of $50-75 \mathrm{~cm}$ in open areas and $30-50 \mathrm{~cm}$ in sheltered areas. Full thawing of soil is usually expected from April 21 to 29. Soil tilth was achieved on May 20 in loam soils, and on May 18 in sandy loam soils. The frost-free period usually lasts 120-135 days, which allows cultivated plants to achieve full ripeness. Permanent snow cover, with an average depth of $35 \mathrm{~cm}$ from 25 November to 2 December, persisted up to 137-143 days. The hydrothermal index was 1.3-1.4. North- and southwest were the prevailing wind direction trends in Moscow region throughout the year.

\subsection{Methodical Approach Applied in Plant Breeding}

Winter wheat samples were introduced into a well-defined crop rotation in late $\mathrm{Au}$ gust with black fallow crops. An SSFK-7M seeder was used, and the sowing density was 500 grains per $\mathrm{m}^{2}$. Mineral fertilizers were applied during the land preparation period at the following rates: $68 \mathrm{~kg} / \mathrm{ha}$ for nitrogen, $60 \mathrm{~kg} / \mathrm{ha}$ for phosphorus and of $30 \mathrm{~kg} / \mathrm{ha}$ for potassium. Furthermore, $50 \mathrm{~kg} / \mathrm{ha}$ of nitrogen was applied as top dressing in spring. The reference cultivars Mironovskaya 808 (k-43920, Ukraine) and, in some years, Polukarlik 3 (k-54508, Ukraine), and te Moscow cultivars, such as Zarya (k-49916), Nemchinovskaya 52 (k-59269), Moskovskaya 39 (k-64160), were planted with intervals of 10 and 50 samples, respectively. The wheat collection was studied in compliance with the VIR Methodical guidelines [40] and the International COMECON list of descriptions for genus Triticum L. [41].

Every year, 350-1085 genotypes of winter wheat were studied, the precursor was complete fallow, the data collected and analyzed annually were germination, overwintering, snow mold damage, frost resistance, Microdochium nivale infestation, vegetation period, plant height, lodging and the weight of 1000 grains. Yield and grain quality were measured 
only for the distinguished varieties. Every year, genotypes distinguished by resistance to Microdochium nivale were statistically evaluated with a standard variety based on yield, weight of 1000 grains and plant height.

The winter agroclimatic conditions of snow mold epiphytotic years $(1978,1986,1989$, $1990,1993,1998,2001,2003,2005,2021)$ in comparison with perennial indications are given in Figures 3 and 4.

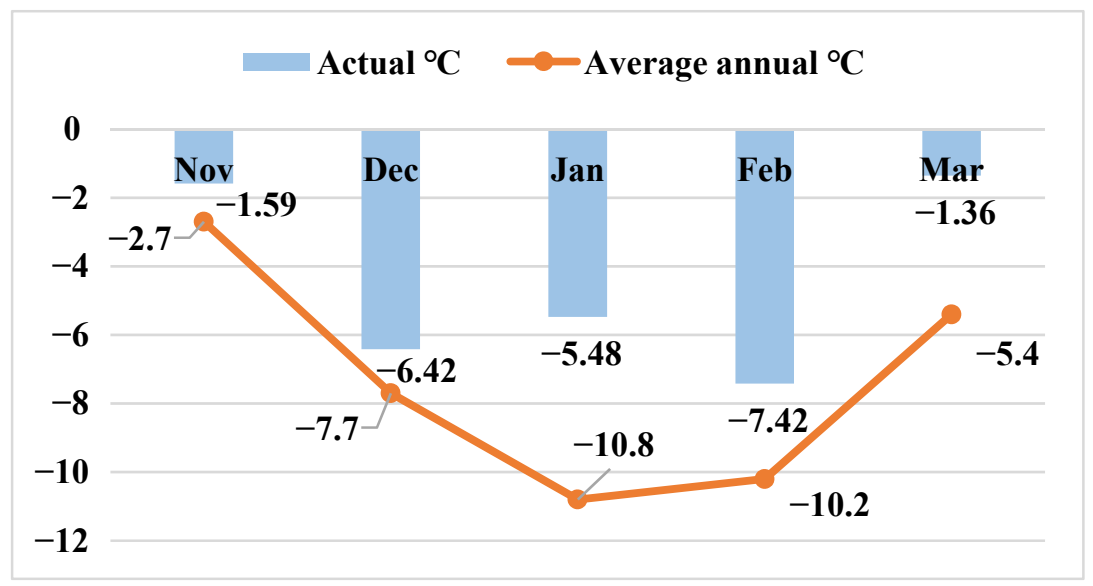

Figure 3. Average monthly temperatures in the epiphytotic years.

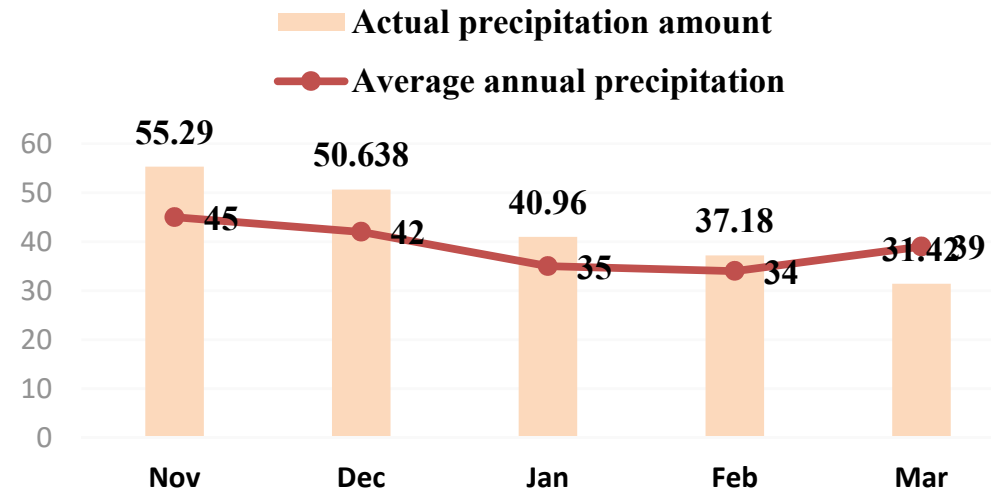

Figure 4. Average monthly precipitation rates in the epiphytotic years.

\subsection{Diseases Infestation Scale}

Snow mold was accounted for in two periods-in autumn, when the tillering phase was reached, and in spring, after snow melting. At least 10 points were selected for accounting at the experimental sites. Visual examination of the sowing was carried out at regular intervals, the number of affected plants per $1 \mathrm{~m}^{2}$ and the degree of their infestation were noted, as well as the form of the disease: diffuse or focal. At each point, 50 plants were selected and evaluated in the laboratory according to the appropriate scale: 0 -absence of disease, 1 -less than $10 \%$ of leaves were affected, 2 - the lower leaves were completely affected, or more than $30 \%$ of the plant was affected, 3-the lower and upper leaves were affected, the degree of damage was more than $70 \%$, shoots were dying, 4 -all leaves and shoots were affected, the plant died [41,42].

\section{Conclusions}

Our perennial investigation and analysis of the results of pink snow mold spread in winter wheat during a number of epiphytotic years has demonstrated that the primary reason for the spread happens to be such abiotic stress factors as the snow covering thawed 
soil at ambient temperature exceeding the norm $\left(-9.5^{\circ} \mathrm{C}\right)$ by $1.0-4.6^{\circ} \mathrm{C}$. Under such conditions winter wheat sprouts keep growing, breathing and burning their nutrient reserves (proteins and carbohydrates). Meanwhile, their immune system gets weaker, rendering the plants susceptible to infections, which are mainly caused by the cryophilic fungi such as Microdochium nivale. The joint effect of abiotic and biotic stress factors results in excessive of crop mortality that it sometimes requires spring wheat reseeding. As a protective measure, we recommend combining agrotechnical methods with nitrogen fertilization in spring. The potential sources of resistance and tolerance to rot and pink snow mold resulting from this study can be recommended to plant breeders of different countries for selection.

Author Contributions: Conceptualization, S.K.T.; methodology, S.K.T. and O.O.B.; software, I.M.K.; validation, S.K.T., O.O.B. and N.Y.R.; formal analysis, S.K.T. and N.Y.R.; investigation, S.K.T., N.Y.R., Y.V.A. and M.Z.A.; resources, S.K.T.; data curation, I.M.K. and R.N.K.; writing-original draft preparation, I.M.K. and E.S.P.; writing-review and editing, N.Y.R. and L.G.T.; visualization, S.K.T.; supervision, S.K.T., O.O.B. and E.V.Z.; project administration, S.K.T. and A.P.G.; funding acquisition, N.Y.R. All authors have read and agreed to the published version of the manuscript.

Funding: The presented study was carried out as a part of Governmental Task for Federal Horticultural Center for Breeding, Agrotechnology and Nursery \#0432-2021-0003 to preserve, enlarge and study the genetic collections of agricultural plants and establish the repositories of the horticultural and small-fruit crops that are free from hazardous viruses; and as a part of Subject Plan for AllRussian Research Institute of Phytopathology \#0598-2019-0005, Official Registration Number ЕГИСУ НИОКТР-АААА-А19-1191212901090. This paper has been supported by the RUDN University Strategic Academic Leadership Program (Rebouh N.Y, statistical and formal analysis). The article was made with support of the Ministry of Science and Higher Education of the Russian Federation in accordance with agreement № 075-15-2020-905.

Institutional Review Board Statement: Not applicable.

Informed Consent Statement: Not applicable.

Data Availability Statement: Not applicable.

Conflicts of Interest: The authors declare no conflict of interest.

\section{References}

1. Xu, X.-M.; Monger, W.; Ritieni, A.; Nicholson, P. Effect of temperature and duration of wetness during initial infection periods on disease development, fungal biomass and mycotoxin concentrations on wheat inoculated with single, or combinations of, Fusarium species. Plant Pathol. 2007, 56, 943-956. [CrossRef]

2. Tronsmo, A.M.; Hsiang, T.; Okuyama, H.; Nakajima, T.A. Low temperature diseases caused by Microdochium nivale. In Low Temperature Plant Microbe Interactions under Snow; Iriki, N., Gaudet, D.A., Tronsmo, A.M., Matsumoto, N., Yoshidaand, M., Nishimune, A., Eds.; Hokkaido National Agricultural Experiment Station: Hokkaido, Japan, 2001; pp. 75-86.

3. Temirbekova, S.; Jafarov, I.; Kulikov, I.; Afanaseva, Y.; Kalashnikova, E. Gene Pool of Winter Wheat from the World Collection of N.I. Vavilov Institute of Plant Industry (VIR) for Biotic Stress Resistance. Pathogens 2021, 10, 514. [CrossRef] [PubMed]

4. Hoshino, T.; Matsumoto, N. Cryophilic fungi to denote in the cryosphere. Fungal Biol. Rev. 2012, 26, 102-105. [CrossRef]

5. Gorshkov, V.; Osipova, E.; Ponomareva, M.; Ponomarev, S.; Gogoleva, N.; Petrova, O.; Gogoleva, O.; Meshcherov, A.; Balkin, A.; Vetchinkina, E.; et al. Rye Snow Mold-Associated Microdochium nivale Strains Inhabiting a Common Area: Variability in Genetics, Morphotype, Extracellular Enzymatic Activities, and Virulence. J. Fungi 2020, 6, 335. [CrossRef]

6. Hsiang, T. All you ever wanted to know about Fusarium patch/Microdochium patch/pink snow mold or whatever that disease is called. Green Master 2009, 44, 13-16.

7. Ioos, R.; Belhadj, A.; Menez, M.; Faure, A. The effects of fungicides on Fusarium spp. and Microdochium nivale and their associated trichothecene mycotoxins in French naturally-infected cereal grains. Crop Prot. 2005, 24, 894-902. [CrossRef]

8. Hudec, K.; Muchová, D. Influence of temperature and species origin on Fusarium spp. and Microdochium nivale pathogenicity to wheat seedlings. Plant Prot. Sci. 2010, 46, 59-65. [CrossRef]

9. Żur, I.A.; Dubas, E.; Pociecha, E.; Dubert, F.; Kolasińska, I.; Płażek, A. Cytological analysis of infection process and the first defence responses induced in winter rye (Secale cereale L.) seedlings inoculated with Microdochium nivale. Physiol. Mol. Plant Pathol. 2011, 76, 189-196. [CrossRef]

10. Gorkovenko, V.S.; Oberyuhtina, L.A.; Kurkina, E.A. The harmfulness of the Microdochium nivale in agrocenosis of winter wheat. Prot. Quar. Plants 2009, 1, 34-35. (In Russian) 
11. Glynn, N.C.; Hare, M.C.; Edwards, S.G. Fungicide seed treatment efficacy against Microdochium nivale and M. majus in vitro and in vivo. Pest Manag. Sci. 2008, 64, 793-799. [CrossRef] [PubMed]

12. Rebouh, N.Y.; Polityko, P.M.; Pakina, E.; Plushikov, V.G.; Norezzine, A.; Gadzhikurbanov, A.; Iguer-Ouada, M. Impact of three integrated crop protection treatments on the varieties of winter wheat (Triticum aestivum L.) in Moscow area, Russia. Res. Crops 2019, 20, 161-168. [CrossRef]

13. Knox, O.G.; McHugh, M.; Fountaine, J.M.; Havis, N.D. Effects of microwaves on fungal pathogens of wheat seed. Crop Prot. 2013, 50, 12-16. [CrossRef]

14. Liu, J.B.; Xu, Y.L.; Li, C.J.; Wei, W.; Ma, L.L. Effect of soybean long term continual cropping on main groups of rhizosphere fungi. Syst. Sci. Compr. Stud. Agric. 2009, 25, 105-113.

15. Campanella, V.; Mandalà, C.; Angileri, V.; Miceli, C. Management of common root rot and Fusarium foot rot of wheat using Brassica carinata break crop green manure. Crop Prot. 2020, 130, 105073. [CrossRef]

16. Karlsson, I.; Friberg, H.; Kolseth, A.K.; Steinberg, C.; Persson, P. Agricultural factors affecting Fusarium communities in wheat kernels. Int. J. Food Microbiol. 2017, 252, 53-60. [CrossRef]

17. Latati, M.; Rebouh, N.Y.; Aouiche, A.; Laouar, M. Modeling the functional role of the microorganisms in the daily exchanges of carbon and nitrogen in intercropping system under Mediterranean conditions. Agron. Res. 2019, 17, 559-573. [CrossRef]

18. Dordas, C. Role of nutrients in controlling plant diseases in sustainable agriculture: A review. Agron. Sustain. Dev. 2008, 28, 33-46. [CrossRef]

19. Hoffland, E.; Jegger, M.J.; van Beusichem, M.L. Effect of nitrogen supply rate on disease resistance in tomato depends on the pathogen. Plant Soil. 2000, 218, 239-247. [CrossRef]

20. Rebouh, N.Y.; Latati, M.; Polityko, P.; Maisam, Z.; Kavhiza, N.J.; Garmasch, N.; Pakina, E.; Lyshko, M.; Engeribo, A.; Orujov, E.; et al. Improvement of weeds management system and fertilisers application in winter wheat (Triticum aestivum L.) cultivation technologies. Agriculture 2021, 67, 76-86. [CrossRef]

21. Summersa, R.W.; Brown, J.K.M. Constraints on breeding for disease resistance in commercially competitive wheat cultivars. Plant Pathol. 2013, 62, 115-121. [CrossRef]

22. Ren, R.; Foulkes, J.; Mayes, S.; Yang, X.; Ray, R.V. Identification of novel quantitative trait loci for resistance to Fusarium seedling blight caused by Microdochium majus and M. nivale in wheat. Field Crops Res. 2016, 191, 1-12. [CrossRef]

23. Bertrand, A.; Castonguay, Y.; Azaiez, A.; Hsiang, T.; Dionne, J. Cold-induced responses in annual bluegrass genotypes with differential resistance to pink snow mold (Microdochium nivale). Plant Sci. 2011, 180, 111-119. [CrossRef] [PubMed]

24. Robbins, M. Backcrossing, Backcross (BC) Populations, and Backcross Breeding; The Ohio State University: Columbus, OH, USA, 2012; $19 p$.

25. Alemu, G. Wheat Breeding for Disease Resistance: Review. J. Microbiol. Biotechnol. 2019, 4, 000142.

26. Temirbekova, S.K.; Kulikov, I.M.; Afanasyeva, Y.V.; Beloshapkina, O.O.; Kalashnikova, E.A.; Kirakosyan, R.N.; Dokukin, P.A.; Kucher, D.E.; Latati, M.; Rebouh, N.Y. The Evaluation of Winter Wheat Adaptation to Climate Change in the Central Non-Black Region of Russia: Study of the Gene Pool Resistance of Wheat from the N.I. Vavilov Institute of Plant Industry (VIR) World Collection to Abiotic Stress Factors. Plants 2021, 10, 2337. [CrossRef]

27. Chekmarev, V.V. Fungus Vicrodochium nivale and effective fungicides to control its development. Colloq. J. 2020, 5, 54-55 [CrossRef]

28. Anonymous. The pink and brown that can snooker your green Hortic. Week 1989, 205, 18-19.

29. Bruehl, G.W. Developing wheats resistant to snow mold. Plant Dis. 1982, 66, 1190-1193. [CrossRef]

30. Gaudet, D.A.; Chen, T.H. Effect of freezing tolerance and low temperature stress on development of cottony snow mold (Coprinus psychomorbidus) in winter wheat. Can. J. Bot. 1988, 66, 1610-1615. [CrossRef]

31. Tkachenko, O.B.; Ovsyankina, A.V.; Shchukovskaya, A.G. Snow molds: History of the study and control. Agric. Biol. 2015, 50, 16-29. [CrossRef]

32. Pociecha, E.; Płazek, A.; Janowiak, F.; Zwierzykowski, Z. ABA level, proline and phenolic concentration, and PAL activity induced during cold acclimation in androgenic Festulolium forms with contrasting resistance to frost and pink snow mould (Microdochium nivale). Physiol. Mol. Plant Pathol. 2008, 73, 126-132. [CrossRef]

33. Hiilovaara-Teijo, M.; Hannukkala, A.; Griffith, M.; Yu, X.-M.; Pihakaski-Maunsbach, K. Snow mold-induced apoplastic proteins in winter rye leaves lack antifreeze activity. Plant Physiol. 1999, 121, 665-674. [CrossRef] [PubMed]

34. Haigh, I.M.; Hare, M.C. The Effect of Freezing Temperatures on Microdochium majus and M. nivale Seedling Blight of Winter Wheat. Int. J. Agron. 2012, 2012, 359017. [CrossRef]

35. Rebouh, N.Y.; Latati, M.; Polityko, P.; Kucher, D.; Hezla, L.; Norezzine, A.; Kalisa, L.; Utkina, A.; Vvedenskiy, V.; Gadzhikurbanov, A.; et al. IInfluence of three cultivation technologies to control Fusarium spp. in winter wheat (Triticum aestivum L.) production under Moscow conditions. Res. Crops 2020, 21, 17-25. [CrossRef]

36. Couteaudier, Y.; Alabouvette, C. Survival and inoculum potential of conidia and chlamydospores of Fusarium oxysporum f.sp. lini in soil. Can. J. Microbiol. 1990, 36, 551-556. [CrossRef] [PubMed]

37. Polityko, P.M.; Kiselev, E.F.; Dolgikh, A.V.; Matjuta, S.V.; Proshchenko, A.L.; Parygina, M.N.; Tonojan, S.V.; Shaklein, I.V.; Volpe, A.A.; Prokopenko, A.G.; et al. Influence of fertilizers and means of plant protection on the grain quality of intensive cultivars of winter wheat (Triticum aestivum L.). Probl. Agrochem. Ecol. 2016, 10-17. (In Russian) 
38. Zargar, M.; Rebouh, N.; Pakina, E.; Gadzhikurbanov, A.; Lyashko, M.; Ortskhanov, B. Impact of climate change on cerealproduction in the highlands of eastern Algeria. Res. Crops 2017, 18, 575-582. [CrossRef]

39. Polityko, P.; Rebouh, N.Y.; Kucher, D.; Vvedenskiy, V.; Kapranov, V.; Atmachian, G.; Behzad, A.; Urazova, E.; Khomenets, N.; Pakina, E.; et al. Productivity and grain quality of three spring wheat (Triticum aestivum L.) cultivars under three cultivation technologies. Eurasian J. Biosci. 2020, 14, 2089-2095.

40. Temirbekova, S.K.; Kulikov, I.M.; Afanasieva, Y.V.; Zuev, E.V.; Beloshapkina, O.O.; Dementiev, A.V. Source material of a winter wheat for a stress-resistant varieties selection. Vestn. Russ. Agric. Sci. 2021, 1, 16-24. (In Russian)

41. Triticum, L. The International COMECON List of Descriptors for the Genus; Institute of Plant Industry: Leningrad, Russia, 1989; 43p.

42. Ishkova, T.I. Diagnostics of the MAIN Fungal Diseases of Grain Crops; VIZR: Saint Petersburg, Russia, 2002; 76p. 